\title{
Waterbath Calibrator with Nine Channels Sensor
}

\author{
Mohammad Rofi' ' ${ }^{\#}$, Syaifudin, Dyah Titisari, Bedjo Utomo \\ Department of Electromedical Engineering Poltekkes Kemenkes, Surabaya \\ Jl. Pucang Jajar Timur No. 10, Surabaya, 60245, Indonesia \\ \#rofixander9@gmail.com, Nyong74@yahoo.com,ti2_sari@gmail.com,
}

\begin{abstract}
Water bath is a laboratory equipment that contains water or special liquid that can maintain the temperature under certain conditions during the specified time interval. For this reason, calibration is needed so that the temperature in the chamber water bath is stable or not. Calibration is carried out by comparing measuring instruments and measuring materials to be calibrated to traceable standards that are traceable to national and international standards. Based on the results of the identification of the problems mentioned above, the author makes a water bath calibrator entitled Water bath Calibrator 9 channel which is very practical, and easy to operate. .This calibration tool uses a $\mathrm{K}$ type thermocouple sensor and also the output is displayed to the character LCD to make it easier for users to retrieve data, the reason for choosing a thermocouple sensor is because the error rate is $+/-1,1 \mathrm{C}$ while the $\mathrm{LM35}$ is $+/-1,4 \mathrm{C}$. The thermocouple temperature sensor can detect the chamber temperature quite well where the Department error is obtained with a comparator of $2 \%$, and the lowest error is $0 \%$.
\end{abstract}

Keywords: temperature, waterbaths, calibration, thermocouple type $\mathrm{K}$.

\section{INTRODUCTION}

A waterbath is laboratory equipment that contains water or special liquid that can maintain the temperature under certain conditions during the specified time interval. waterbath function to create a constant temperature and is used as an incubation tool in microbiological analysis besides that waterbath can be used at low temperatures $30^{\circ} \mathrm{C}$ to $100^{\circ} \mathrm{C}$ and evaporates substances or solutions with temperatures that are not too high. water bath works by heating water with a heater until the water temperature rises and according to the temperature we choose, the heater will stop heating the water when a predetermined time has been reached [1].

Calibration is an activity to determine the conventional truths of the value of the appointment of measuring instruments and measuring materials. calibration is carried out by comparing measuring instruments and measuring materials to be calibrated to traceable standards traceable to national or international standards. whereas calibration goals can be determined by conventional truth deviations, the value of a measuring instrument, or the nominal dimension deviation that should be a measuring material [2].

In the water bath device, to keep the temperature stable, according to the setting, and the temperature distribution is evenly distributed, it requires tool calibration activities. calibration in the water bath is at least done twice per year, waterbath thermometers must be checked by the officer using a calibrated thermometer. The storage test interval (deviation) must be documented and recorded on the equipment book. But, based on the reality in the field the internal water bath calibration is done by using 1 dip thermometer placed at 9 points alternately so that the results of the measurement of the nine points cannot be known in real-time.
In a previous study Defry Diba Farhandinata conducted a study on, Waterbath Internal Calibrator, this study was designed to detect the temperature of the waterbath at 6 measurement points, the temperature sensor used by PT100, then the results are displayed on graph plotting by utilizing the Delphi application and there is SD card storage as data storage, the weakness in this study is still using 6 measurement points in 3 sensors .

In a previous study Rizal Imam Rabbani conducted a study of, Portable Waterbath Calibrators (3 Channels) Equipped with Data Storage, This study was designed to detect the temperature of the waterbath at 9 measurement points, the temperature sensor used by LM35, in this study the weakness was still using 3 sensors in 9 measurement points .

On the use of thermocouple sensors in previous studies applied in sterilizers and measurement results data from temperature calibration devices showed the largest percentage of errors which is $0.07 \%$ at a temperature of 40 and $150^{\circ}$ Celsius and shows the smallest of $0 \%$ at 200,90 and $60^{\circ}$ Celsius[3]. Weakness in LM35 sensors in previous studies, LM35 sensors have not been able to work properly in detecting increases in water temperature and the percentage of measurement errors in op-amp output ranges from $0.73 \%$ $1.93 \%[4]$.

Based on the results of the identification of the problems mentioned above, the author made a waterbath calibrator entitled Waterbath Calibrator 9 channel which is very practical, and easy to operate. The difference from previous research lies in the type of sensor and the number of sensors. This calibration tool uses a type $\mathrm{K}$ thermocouple sensor and also displays the character LCD to make it easier for users to retrieve data, the reason I chose a thermocouple sensor is due to the level of error $+/-1,1 \mathrm{C}$ while the LM35 level is $+/-1,4 \mathrm{C}$. 


\section{MATERIALS AND METHODS}

\section{A. Experimental Setup}

In this research method using the schutzart DIN 400550 type $\mathrm{W} 350$ water bath in measurement temperatures of $30^{\circ} \mathrm{C}, 40^{\circ} \mathrm{C}, 50^{\circ} \mathrm{C}, 60^{\circ} \mathrm{C}, 70^{\circ} \mathrm{C}, 80^{\circ} \mathrm{C}$ and $90^{\circ} \mathrm{C}$ with a range of $10^{\circ} \mathrm{C}$ and do enclosure calibration method in 9 measurement points. Measurements in this calibration were carried out five times in the experiment and searched for the average value and error.

\section{1).Materials and Tool}

In this study the material used is the MAX6675 module as an ADC from the Thermocouple sensor, Arduino MEGA 5260 as a controller of the entire circuit, Powerbank battery as a power supply, character LCD to display the output on measurements and thermocouple type $\mathrm{K}$ sensors for temperature detectors inside the chamber waterbath.

\section{2). Experiment}

In this study, after the tool has been completed, the next step will be tested by burning the tip of the thermocouple sensor, the purpose is whether the tool module has displayed the test results output temperature to the character LCD and can be put into a water heater using a thermometer as a comparison or comparison.

\section{B. The Diagram Block}

The flow of reading on the blog output data diagram in Fig 1 , start as the beginning of the operation of the circuit, on / off as a switch on the analog device from reading the temperature of the thermocouple if Arduino is then output to the LCD character.

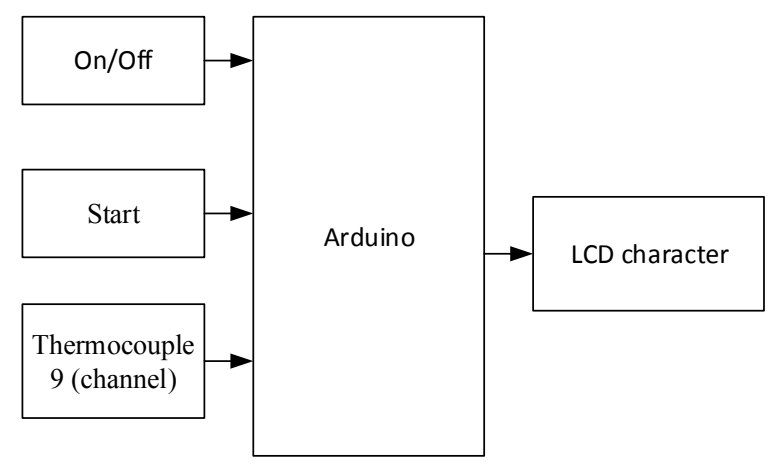

Fig. 1. Blog diagram calibrator waterbath.

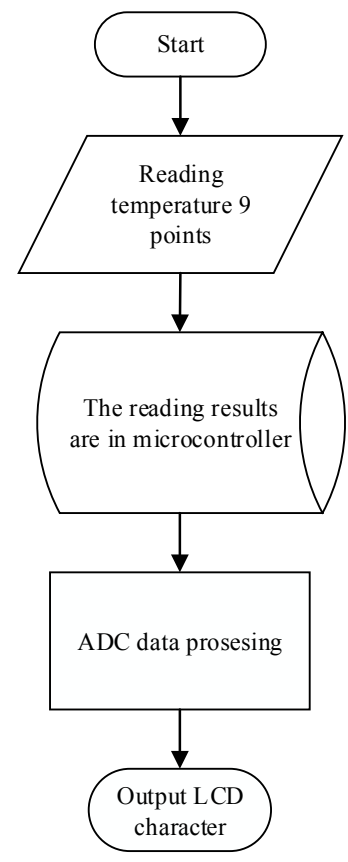

Fig. 2. Flow chart diagram.

\section{The Flowchart}

The reading flow in fig 2 , the sensor reading starts with the start button, the reading is done with 9 measurement points with the enclosure method, data processing is performed by Arduino which is converted by the ADC and displayed on the character LCD.

\section{The Analog Circuit}

In this case, there is a max 6675 circuit connected to the thermocouple connector in Figure 3 and the character LCD circuit in Fig 4.

\section{1). Max 6675 circuit}

The MAX 6675 circuit for processing data on the thermocouple temperature sensor from analog data is converted to digital data because in the IC MAX 6675 there is already an ADC data processor like Fig 3 below.

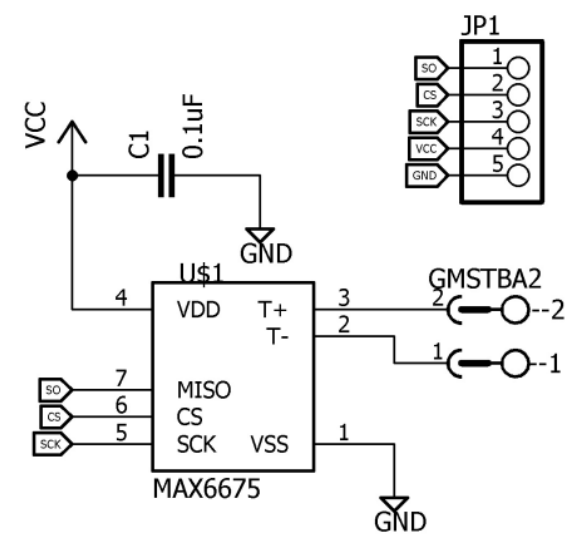

Fig. 3. MAX 6675 Circuit 


\section{2). Character LCD circuit}

The LCD circuit below works with the Arduino data processing system to display to the LCD display. The voltage distribution is given to adjust the contrast on the LCD display. LCD display used with a size of $20 \times 4$.

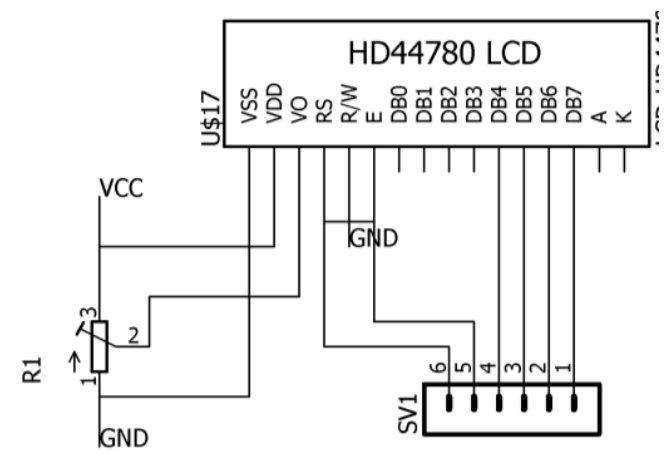

Fig. 4. LCD character circuit

\section{RESULTS}

In this study, a comparison of the results of the data with a predetermined comparator, measurement in the chamber waterbath has been compared.

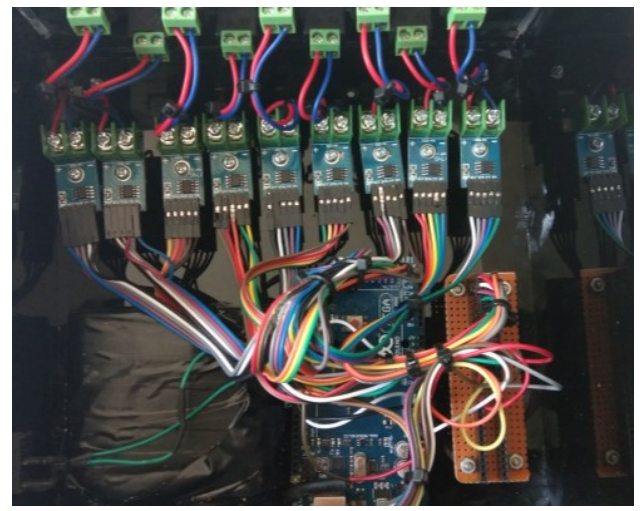

Fig. 5. The calibrator waterbath desain

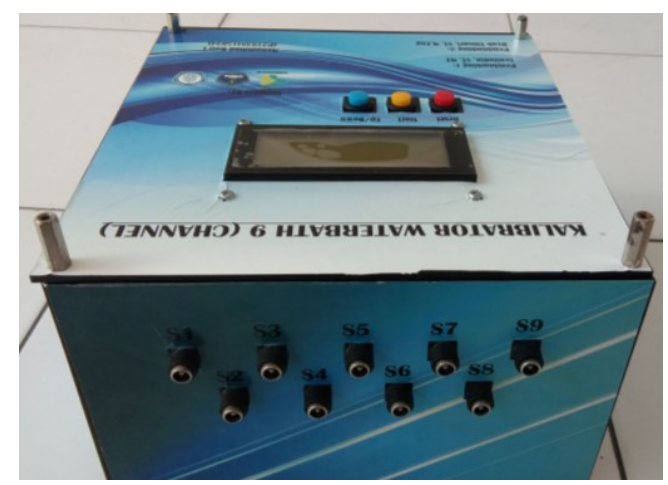

Fig. 6. Box calibrator waterbath desain

\section{The calibrator waterbath Design}

Photo section analog and digital waterbath calibrator review in Figure. 9 and Figure. 10 each. The digital section consists of $9 \max 6675$ modules. There are also several connectors as thermocouple sensor connectors. The digital part consists of an Arduino Mega 2560 microcontroller which is the main board of the device module, Powebank as the power supply on the device and LCD character as the output of the reading results.

\section{The Listing Program for Arduino calibrator waterbaths 9 (channel)}

Listing of data processing programs on Arduino starts with include as a library or real data from the sensor readings using an Arduino digital pin connected to the module.

\section{Listing program MAX 6675}

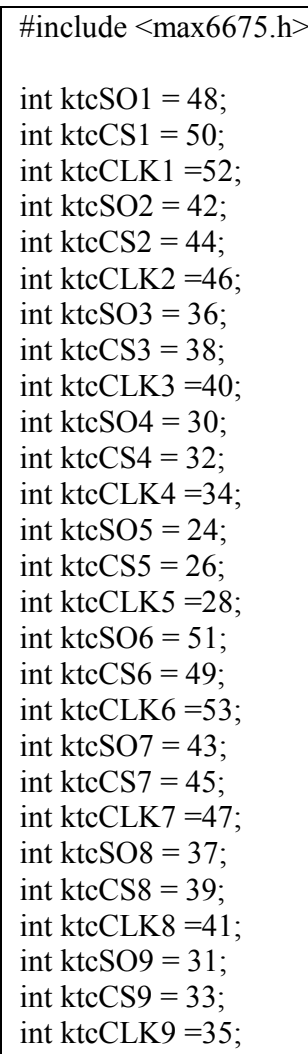

MAX6675 ktc1(ktcCLK1, ktcCS1, ktcSO1); MAX6675 ktc2(ktcCLK2, ktcCS2, ktcSO2); MAX6675 ktc3(ktcCLK3, ktcCS3, ktcSO3); MAX6675 ktc4(ktcCLK4, ktcCS4, ktcSO4); MAX6675 ktc5(ktcCLK5, ktcCS5, ktcSO5); MAX6675 ktc6(ktcCLK6, ktcCS6, ktcSO6); MAX6675 ktc7(ktcCLK7, ktcCS7, ktcSO7); MAX6675 ktc8(ktcCLK8, ktcCS8, ktcSO8); MAX6675 ktc9(ktcCLK9, ktcCS9, ktcSO9);

lcd.setCursor( $(0,0)$;

lcd.print("T1= ");

lcd.setCursor $(3,0)$; 
lcd.print((ktc1.readCelsius()-2),1);

lcd.setCursor $(8,0)$;

lcd.print("C ");

lcd.setCursor $(0,1)$;

lcd.print("T2= ");

lcd.setCursor $(3,1)$;

lcd.print((ktc2.readCelsius()-2),1);

lcd.setCursor $(8,1)$;

lcd.print("C ");

lcd.setCursor $(0,2)$;

lcd.print("T3= ");

lcd.setCursor( 3,2$)$;

lcd.print((ktc3.readCelsius()-2),1);

lcd.setCursor $(8,2)$;

lcd.print("C ");

lcd.setCursor(0,3);

lcd.print("T4=");

lcd.setCursor(3,3);

lcd.print((ktc4.readCelsius()-2),1);

lcd.setCursor $(8,3)$;

lcd.print("C ");

lcd.setCursor(10,0);

lcd.print("T5= ");

lcd.setCursor(13,0);

lcd.print((ktc5.readCelsius()-2),1);

lcd.setCursor(18,0);

lcd.print("C ");

lcd.setCursor(10,1);

lcd.print("T6= ");

lcd.setCursor(13,1);

lcd.print((ktc6.readCelsius()-2),1);

lcd.setCursor(18,1);

lcd.print("C ");

lcd.setCursor(10,2);

lcd.print("T7= ");

lcd.setCursor $(13,2)$;

lcd.print((ktc7.readCelsius()-2),1);

lcd.setCursor(18,2);

lcd.print("C ");

lcd.setCursor(10,3);

lcd.print("T8= ");

lcd.setCursor(13,3);

lcd.print((ktc8.readCelsius()-2),1);

lcd.setCursor(18,3);

lcd.print("C ");

delay(500);

lcd.setCursor( $(0,0)$;

lcd.print("T9= ");

lcd.setCursor( $(3,0)$;

lcd.print((ktc9.readCelsius()-2),1);

lcd.setCursor $(8,0)$;

lcd.print("C ");

delay (500);

\section{Listing program lcd character}

Is a program resulting from ouput output that is connected to the character LCD.

Listing Program 2. Program LCD karakter

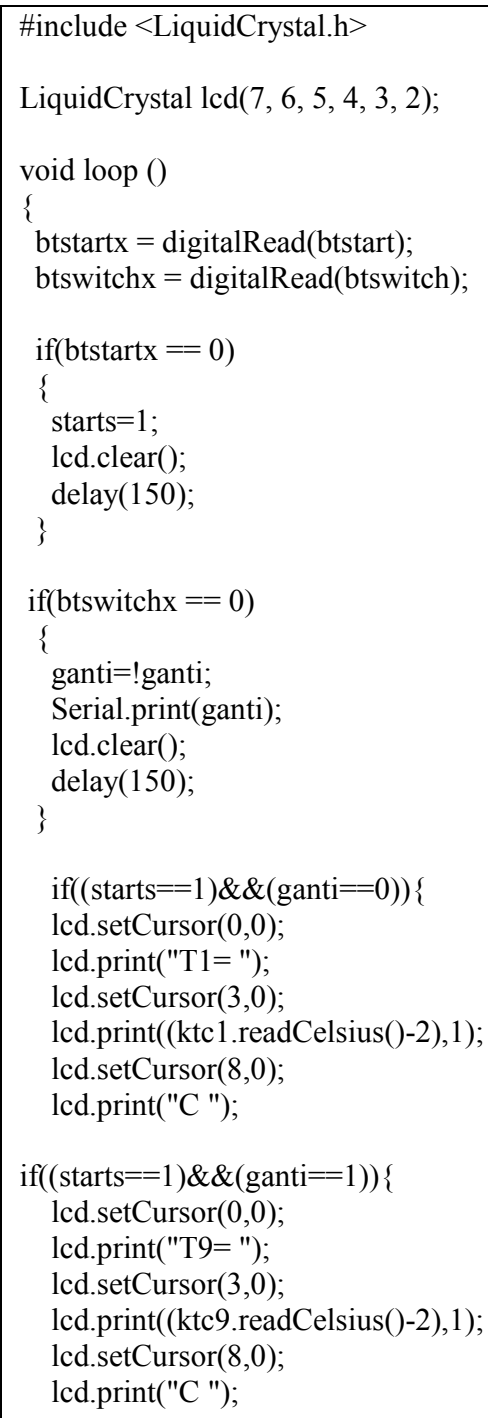


4. Temperature Measurement Results $30^{\circ} \mathrm{C}$

TABLE I. SET PoINT $30^{\circ} \mathrm{C}$

\begin{tabular}{|c|c|c|}
\hline Set & sensor & Error \\
\hline \multirow{9}{*}{$30^{\circ} \mathrm{C}$} & 1 & 0,01 \\
\hline & 2 & 0,00 \\
\hline & 3 & 0,01 \\
\hline & 4 & 0,00 \\
\hline & 5 & 0,00 \\
\hline & 6 & 0,00 \\
\hline & 7 & 0,01 \\
\hline & 8 & 0,00 \\
\hline & 9 & 0,02 \\
\hline
\end{tabular}

is the temperature measurement data on the Schutzart brand DIN $400550 \mathrm{~W} 350$ type waterbath at the $30^{\circ} \mathrm{C}$ set point in 1 hour or 60 minutes, the measurement was carried out as many as 5 measurements on each measurement 9 channels. From the results of the table the measurement of the table above on the Waterbath there is the biggest error in channel 9 which is $2 \%$ and the smallest error is located in channels 2,4,5,6 and 8 of $0 \%$. The results of the error are obtained from the number of calculation results on average - there are differences in values at the time of measurement. For the results of the number of errors also occur from the quality of the sensor module of the tool with the sensor comparator and also there is a comparison of measuring instruments and comparable devices that have been calibrated by BPFK.

5. temperature measurement results $50^{\circ} \mathrm{C}$

\begin{tabular}{ccc} 
& TABLE II. & SETPOINT $30^{\circ} \mathrm{C}$ \\
\hline Set & sensor & Error \\
\hline & 1 & 0,00 \\
\cline { 2 - 3 } $50^{\circ} \mathrm{C}$ & 2 & 0,00 \\
\cline { 2 - 3 } & 3 & 0,02 \\
\hline
\end{tabular}

\begin{tabular}{|c|c|}
\hline 4 & 0,02 \\
\hline 5 & 0,01 \\
\hline 6 & 0,02 \\
\hline 7 & 0,00 \\
\hline 8 & 0,02 \\
\hline 9 & 0,02 \\
\hline
\end{tabular}

Is the temperature measurement data on the Schutzart brand DIN $400550 \mathrm{~W} 350$ type water bath at a set point of $50^{\circ} \mathrm{C}$ in 1 hour or 60 minutes, the measurement is carried out as many as 5 measurements on each - each of the 9 channels. From the results of the table, the measurement of the table above in the water bath there is the biggest error in channels 3,4,6,8 and 9 which are $2 \%$ and the smallest error is located in channels 1,2 and 7 of $0 \%$. The results of the error are obtained from the number of calculation results on average - there are differences in values at the time of measurement. For the results of the number of errors also occur from the quality of the sensor module of the tool with the sensor comparator and also there is a comparison of measuring instruments and comparable devices that have been calibrated by BPFK.

\section{DISCUSSION}

After comparing the results between the module and the comparative measuring instrument, the average error in the measurement results of the waterbath found that there was the largest error of $2 \%$ and the smallest error was $0 \%$. The results of the error are obtained from the number of calculation results on average - there are differences in values at the time of measurement. The test results for the results of the number of errors also occur from the quality of the sensor module of the tool with the sensor of the comparator and also in the comparison of measuring modules and comparable devices that have been calibrated. The results of testing the data retrieval time required an interval of 10 to 30 minutes to reach the predetermined set temperature. Then, it takes 1 hour or 60 minutes to wait for the spread of temperature in the chamber to be reached. After the time to achieve temperature stability is fulfilled, the data retrieval process can be carried out.

\section{Conclusion}

This study shows that the tool can be used in the field of calibration, especially waterbath temperature measuring devices or also in other fields of temperature measurement and 
the thermocouple temperature sensor can detect the temperature of the chamber quite well where the measurement error is $2 \%$ of the measurement average with there is the smallest error $0 \%$ on the device.

\section{REFERENCES}

[1] H. G. Ariswati, J. Teknik, E. Politeknik, K. Surabaya, L. Air, and S. Control, "No Title," 2016.

[2] S. Fitra and S. Samsiana, "Kalibrasi Termometer Digital Metode Sensor Plus Indikator," JREC (Journal Electr. Electron., vol. 2, no. 1, pp. 1-5, 2014.

[3] M. Sofyan, A. Pudji, and Syaifuddin, "Alat Kalibrasi Suhu dengan Thermocouple dilengkapi Thermohygrometer," pp. 1-8, 2016.

[4] D. K. Allo, M. E. Dringhuzen J. Mamahit. S.T., M. K. Drs. Bahrun, and M. Novi M. Tulung, ST, "Rancang Bangun Alat Ukur Temperatur Untuk Mengukur Selisih Dua Keadaan,” E-Journal Tek. Elektro dan Komput., p. 3, 2013. 